\title{
The effect of growth conditions of Corynebacterium glutamicum on the transformation frequency obtained by electroporation
}

\author{
Jill A. HaYnes ${ }^{1}$ and Margaret L. Britz ${ }^{* 2}$ \\ ${ }^{1}$ Commonwealth Serum Laboratories, 45 Poplar Road, Parkville, Victoria 3052, Australia \\ 2 Division of Biotechnology, Commonwealth Scientific and Industrial Research Organization, Clayton Victoria 3168, \\ Australia
}

(Received 23 March 1989; revised 12 September 1989; accepted 29 September 1989)

\begin{abstract}
A rapid and efficient method of transforming Corynebacterium glutamicum by electroporation is described. A number of factors are important in determining the level of transformation obtained. Cells grown in the presence of glycine and isonicotinic acid hydrazide and harvested in early exponential growth phase were much easier to transform. The recovery medium on which transformants were isolated also had a significant effect on the number of transformants obtained because cells were osmotically or electrochemically sensitive following electroporation. Transformation efficiencies of up to $5 \times 10^{5}$ transformants per $\mu$ g plasmid DNA with homologously derived DNA and $2 \times 10^{3}$ transformants per $\mu \mathrm{g}$ of DNA derived from Escherichia coli were obtained.
\end{abstract}

\section{Introduction}

Non-pathogenic saprophytic coryneform bacteria, including species such as Corynebacterium glutamicum and Brevibacterium lactofermentum, are widely used for industrial production of amino acids and nucleotides. As classical mutation and selection programmes for strain improvement can be complemented by recombinant DNA approaches, efforts have been made to develop efficient transformation systems for these species (Martin et al., 1987).

Most published protoplast transformation protocols are based on methods developed for Bacillus subtilis and Streptomyces species and involve lysozyme treatment followed by PEG-stimulated uptake of DNA. However, the unusual nature of their cell wall structures, which include corynemycolic acids, make the corynebacteria resistant to lysozyme unless they have been grown in the presence of cell wall inhibitors which modify these structures. For example, 0.3-0.5 $\mathrm{U}$ penicillin $\mathrm{G} \mathrm{ml^{-1 }}$ (Katsumata et al., 1984; Santamaria et al., 1984) or 0.5$2.5 \%(\mathrm{w} / \mathrm{v})$ glycine (Yoshihama et al., 1985; Thierbach et al., 1988) have been used during growth as a prerequisite to protoplast or spheroplast generation. Generally, strains of Brevibacterium lactofermentum are more sus-

Abbreviations: EPB, electroporation buffer; INH, isonicotinic acid hydrazide; LAG, Luria agar; LB(G) Luria broth (supplemented with $0.5 \%$ glucose); NAG, nutrient agar. ceptible to lysozyme treatment than are species of $C$. glutamicum (Martin et al., 1987). Using such approaches, reported transformation frequencies have varied between $10^{2}$ and $10^{5}$ transformants $(\mu \mathrm{g} \text { DNA })^{-1}$ in $C$. glutamicum (Serwold-Davis et al., 1987; Thierbach et al., 1988; Yoshihama et al., 1985), and up to $10^{6}$ transformants $(\mu \mathrm{g} \mathrm{DNA})^{-1}$ in B. lactofermentum (Santamaria et al., 1985), depending on the methodology used, the species or strains, the plasmid and the source of the DNA. DNAs isolated from heterologous species transform at much lower frequencies, suggesting the presence of restriction and modification systems in the corynebacteria which differ from those found in donor species: for example, Serwold-Davis et al. (1987) reported 0.2 transformants per $\mu \mathrm{g}$ of DNA purified from Escherichia coli. Indeed Thierbach et al. (1988) suggested that temporary inactivation of restriction systems by heat treatment improves frequencies for heterologous DNA transformation but these frequencies remained low [4060 transformants ( $\mu \mathrm{g}$ DNA) $)^{-1}$ for $C$. glutamicum spheroplasts]. Despite the success of these methods, spheroplast or protoplast transformation remains a tedious and lengthy procedure and with this in mind we have investigated an alternative transformation system using electroporation. Electroporation involves the application of a brief, high-voltage pulse to a suspension of cells and DNA which results in transient membrane permeability and subsequent uptake of DNA. Most previous studies on electroporation carried out with $E$. coli 
strains such as LE392 and DH5 $\alpha$ (Dower et al., 1988) have shown that high levels of transformation are possible [up to $4 \times 10^{6}$ transformants $\left(\mu \mathrm{g}\right.$ DNA) ${ }^{-1}$ ].

Many Gram-positive bacteria, including Lactobacillus (Chassy \& Flickinger, 1987), Streptococcus (Powell et al., 1988) and Clostridium (Allen \& Blaschek, 1988), have been transformed successfully by electroporation. The reported transformation efficiencies vary greatly, from $10^{2}-10^{3}$ transformants ( $\left.\mu \mathrm{g} \mathrm{DNA}\right)^{-1}$ for $\mathrm{Cl}$. perfringens (Allen \& Blaschek, 1988) to $1 \times 10^{4}-5 \times 10^{5}$ transformants $(\mu \mathrm{g} \text { DNA) })^{-1}$ for $S$. lactis (Powell et al., 1988). However, the latter workers found that a mild lysozyme pre-treatment of the cells was necessary to achieve these levels and, without this, only $10^{2}$ transformants ( $\mu$ g DNA) $)^{-1}$ were obtained. Chassy \& Flickinger (1987) obtained up to $8.5 \times 10^{4}$ transformants $(\mu \mathrm{g}$ DNA) $)^{-1}$ with species of Lactobacillus.

In this paper, we describe an efficient and rapid method of transforming C. glutamicum using electroporation. A number of factors which were found to influence the transformation efficiency and frequency were investigated and are reported here.

\section{Methods}

Bacterial strains and plasmids. The $C$. glutamicum strains used were: AS019, a spontaneously rifampicin-resistant mutant of ATCC 13059 (Yoshihama et al., 1985) obtained from A. J. Sinskey, Massachusetts Institute of Technology, USA; CG2, obtained from Queensland University Culture Collection (no. 2704); and MLB131, an auxotrophic derivative of AS019 (Best \& Britz, 1986). The B. lactofermentum strain BL1 was a derivative of ATCC 21798 obtained from P. Rogers, University of New South Wales, Australia. E. coli strain HB101 has been described previously (Maniatis et al., 1982). This strain lacks some of the $E$. coli restriction and modification systems (Raleigh, 1987).

Three plasmids were used: pHY $416 \mathrm{Cm} / \mathrm{Km}(9.1 \mathrm{~kb})$ is a Bacillus subtilis-C. glutamicum shuttle vector (Britz \& Best, 1986; Yoshihama et al., 1985); pCSL17 (7.2 kb) is an $E$. coli shuttle vector constructed by sub-cloning the $C$. glutamicum ori from $\mathrm{pHY} 416 \mathrm{Cm} / \mathrm{Km}$ into pBR322 and inserting Tn903 (A. Hodgson and others, unpublished); pUL340 $(5.8 \mathrm{~kb})$ is a $B$. lactofermentum plasmid kindly provided by J. F. Martín, University of Leon, Spain (Santamaria et al., 1984). All three plasmids express kanamycin resistance in C. glutamicum.

Culture conditions and media. $C$. glutamicum and B. lactofermentum were routinely grown in Luria broth (LB; Miller, 1972) supplemented with $0.5 \%$ glucose (LBG), at $30{ }^{\circ} \mathrm{C}$ and 200 r.p.m. Growth was monitored by measuring optical density at $600 \mathrm{~nm}$. Glycine $(0.5-6.5 \%)$ and isonicotinic acid hydrazide (INH) $\left(4-8 \mathrm{mg} \mathrm{ml}^{-1}\right)$ were added from sterile stock solutions [ $20 \%(\mathrm{w} / \mathrm{v})$ glycine and $100 \mathrm{mg}$ INH ml-1].

To obtain the total viable count before and after electroporation, cells were diluted in SMMC buffer $(0.7 \mathrm{M}$-sucrose; $50 \mathrm{mM}$-maleic acid; $10 \mathrm{mM}^{-\mathrm{MgCl}_{2}} \cdot 6 \mathrm{H}_{2} \mathrm{O} ; 10 \mathrm{mM}-\mathrm{CaCl}_{2} ; \mathrm{pH} \mathrm{6.5)}$ and spread onto nutrient agar [NAG; Oxoid Nutrient Broth no. 2 supplemented with $0.5 \%$ glucose and solidified with $1.0 \%(w / v)$ agar] or ET agar (Best \& Britz, 1986). Presumptive transformants were isolated on ET agar, NAG or Luria agar (LAG; LBG solidified with $1.0 \%$ agar), all supplemented with kanamycin sulphate $\left(50 \mu \mathrm{g} \mathrm{ml}^{-1}\right)$.

$E$. coli $\mathrm{HB} 101$ was grown in LBG at $37^{\circ} \mathrm{C}$ and 200 r.p.m. and was harvested when the $\mathrm{OD}_{600}$ was approximately 1.0 .
Rlasmid isolation. Plasmid DNA was isolated from $E$. coli by an alkaline lysis method and purified by $\mathrm{CsCl}_{2}$ density gradient centrifugation (Maniatis et al., 1982). C.glutamicum and B. lactofermentum DNA was isolated using a modification of the method of Santamaria et al. (1984). Cells were grown for approximately $18 \mathrm{~h}$ at $30^{\circ} \mathrm{C}$ in a rotary shaker at 200 r.p.m. in $400 \mathrm{ml} \mathrm{LBG}$ supplemented with kanamycin $\left(50 \mu \mathrm{g} \mathrm{ml}^{-1}\right)$ and glycine $(2.5 \%)$. When the $\mathrm{OD}_{600}$ had reached $\geqslant 1 \cdot 0$, the cells were collected by centrifugation, resuspended in $20 \mathrm{ml}$ lysis buffer ( $2 \mathrm{mg}$ lysozyme $\mathrm{ml}^{-1}$ in $10 \mathrm{mM}$-Tris, pH 8.0; 0.7 Msucrose; $10 \mathrm{mM}-\mathrm{CaCl}_{2} ; 10 \mathrm{mM}-\mathrm{MgCl}_{2} .6 \mathrm{H}_{2} \mathrm{O} ; 0.05 \% \mathrm{KH}_{2} \mathrm{PO}_{4} ; 0.01 \%$ BSA) and incubated for $2 \mathrm{~h}$ at $30^{\circ} \mathrm{C}$ with gentle shaking (100 r.p.m.). Then $5 \mathrm{ml} 0.5 \mathrm{M}-\mathrm{EDTA}, \mathrm{pH} 8$, was added and the mixture was incubated at $30^{\circ} \mathrm{C}$ for $30 \mathrm{~min}$ before adding $50 \mathrm{ml} 1 \% \mathrm{SDS} / 0 \cdot 1 \mathrm{M}-\mathrm{NaOH}$ and heating at $56^{\circ} \mathrm{C}$ for approximately $10 \mathrm{~min}$. Chromosomal DNA was precipitated using potassium acetate and plasmid DNA was subsequently collected following 2-propanol precipitation prior to purification on $\mathrm{CsCl}_{2}$ density gradients, as described by Maniatis et al. (1982).

Transformation protocols. $E$. coli HB101 was transformed either by the $\mathrm{CaCl}_{2}$-induced competence method, as described by Maniatis et al. (1982), or by electroporation as detailed by Dower et al. (1988). Protoplasts of C. glutamicum AS019 and MLB131 were prepared as described previously (Best \& Britz, 1986). A volume of suspension (1 $\mathrm{ml}$, containing up to $10^{9}$ cells) was centrifuged and cells were resuspended in $50 \mu \mathrm{l}$ TSMC buffer $\left(10 \mathrm{mM}-\mathrm{MgCl}_{2} \cdot 6 \mathrm{H}_{2} \mathrm{O} ; 30 \mathrm{~mm}\right.$ $\mathrm{CaCl}_{2} \cdot 2 \mathrm{H}_{2} \mathrm{O}$; $500 \mathrm{~mm}$-sodium succinate; $50 \mathrm{~mm}$-Tris; $\mathrm{pH} 7 \cdot 5$ ), and then $30 \mu \mathrm{l}$ DNA in TSMC was added. After $5 \mathrm{~min}$ on ice, $0.5 \mathrm{ml} \mathrm{PEG}$ $6000(25 \%, w / v$, in TSMC) was added, the contents mixed by inversion and the tube placed on ice for $2 \mathrm{~min}$, then at $37^{\circ} \mathrm{C}$ for $2 \mathrm{~min}$. The suspension was diluted 10-fold in LB/TSMC and incubated at $30^{\circ} \mathrm{C}$ for $90 \mathrm{~min}$ with gentle shaking. Cells were collected by centrifugation, concentrated 15-fold and viable counts performed on ET and ET-Km plates after diluting in SMMC. Transformants regenerated after 2-10 d at $30^{\circ} \mathrm{C}$.

Transformation by electroporation was carried out using the Gene Pulser apparatus (Bio-Rad) with either $0.2 \mathrm{~cm}$ or $0.4 \mathrm{~cm}$ cuvettes (BioRad). The method used with $0.4 \mathrm{~cm}$ and $0.2 \mathrm{~cm}$ cuvettes varied in the washing and suspension solutions and in the volumes used. Cells were routinely harvested by centrifugation at $\mathrm{OD}_{600}$ between $0 \cdot 15$ and $0 \cdot 25$, unless otherwise stated.

The first method, employing $0.4 \mathrm{~cm}$ cuvettes, was essentially that described by the manufacturers for use with $E$. coli. The cells were washed in one culture volume of ice-cold electroporation buffer (EPB) (0.5 M-sucrose; $1 \mathrm{~mm}-\mathrm{MgCl}_{2} ; 7 \mathrm{mM}-\mathrm{K}_{2} \mathrm{HPO}_{4} / \mathrm{KH}_{2} \mathrm{PO}_{4} ; \mathrm{pH} \mathrm{7.4)}$, resuspended in approximately 0.02 culture volumes of ice-cold EPB and held on ice until required. Plasmid DNA (up to $50 \mu \mathrm{l}$ ) was thoroughly mixed with $0.8 \mathrm{ml}$ of cell suspension (about $10^{9}$ cells) in a chilled cuvette. Cells were exposed to a single pulse $(2.5 \mathrm{kV}, 25 \mu \mathrm{F})$ unless otherwise stated.

When $0.2 \mathrm{~cm}$ cuvettes were used the cells were washed in one culture volume of $15 \%(\mathrm{v} / \mathrm{v})$ glycerol and resuspended in 0.002 culture volumes of $15 \%$ glycerol. The concentrated cells $(40 \mu \mathrm{l}$ containing approximately $10^{9}$ cells) were transferred to a cold $1.5 \mathrm{ml}$ polypropylene tube $; 1-2 \mu \mathrm{l}$ DNA was added and the suspension was mixed. Cells were transferred to the cuvette and exposed to a single pulse $(2.5 \mathrm{kV}, 25 \mu \mathrm{F})$ unless otherwise stated. The output of the pulse generator was directed through a Pulse Controller unit containing two $10 \Omega$ resistors in series and two $100 \Omega$ resistors in parallel circuit with the sample.

Time constants for both methods were $4.5-5.0 \mathrm{~ms}$. Immediately following the pulse, cells from $0.4 \mathrm{~cm}$ cuvettes were diluted $1: 10$ in LBG and the cells from $0.2 \mathrm{~cm}$ cuvettes were diluted $1: 25$ in LBG. They were then incubated for $1 \mathrm{~h}$ at $30^{\circ} \mathrm{C}$ before plating for viable counts and selection of kanamycin-resistant cells on ET, NAG and LAG plates.

Characterization of transformed cells. Transformants were scored initially after $48 \mathrm{~h}$ at $30^{\circ} \mathrm{C}$, then after $4 \mathrm{~d}$ of growth; duplicate samples 
were scored and means calculated. Kanamycin resistance of presumptive transformants was confirmed by replica plating onto LAG containing kanamycin $\left(50 \mu \mathrm{g} \mathrm{ml}^{-1}\right)$. The presence of plasmid DNA in presumptive transformants was confirmed by agarose gel electrophoresis of crude extracts. Restriction endonuclease patterns of $\mathrm{CsCl}_{2}$ density gradient-purified plasmids were used to confirm the structural integrity of transformed plasmid DNA. Restriction endonuclease digestions were performed as specified by the manufacturers (Bethesda Research Laboratories) with a series of single and multiple restriction digests. DNA fragment sizes were compared with digests of $\mathrm{HindIII-}$ digested $\lambda$ DNA (BRL).

Transformation efficiency was calculated as c.f.u. per $\mu \mathrm{g}$ of plasmid DNA added. To account for variations in the number of cells treated, transformation frequencies were calculated as transformants per number of cells pulsed.

\section{Results and Discussion}

Initial attempts at obtaining transformants of $C$. glutamicum by electroporation involved using lateexponential-phase cells grown in LBG and pCSL17 which had been isolated from strain AS019: $0.4 \mathrm{~cm}$ cuvettes were used with a pulse of $6.25 \mathrm{kV} \mathrm{cm}^{-1}, 25 \mu \mathrm{F}$. This approach yielded disappointing results, as only 10 100 transformants ( $\mu \mathrm{g}$ DNA) $)^{-1}$ were obtained. However, this prompted the following investigations which showed that a combination of several parameters was important in achieving a greatly improved efficiency of transformation. The majority of experiments were performed using the $0.4 \mathrm{~cm}$ cuvettes but when the $0.2 \mathrm{~cm}$ cuvettes became available, these were also used.

\section{Influence of glycine and INH in the growth medium on electroporation efficiency}

The addition of both glycine $(2.5 \%, \mathrm{w} / \mathrm{v})$ and INH $(4 \mathrm{mg}$ $\mathrm{ml}^{-1}$ ) to $C$. glutamicum during growth has been found to improve the frequency of transformation in protoplast transformation using PEG (M. L. Britz, unpublished). Using electroporation, we found that growth in the presence of glycine $(2.5 \%)$ increased the number of cells transformed with pCSL17 DNA approximately 10-fold and that the further addition of INH produced almost another 10-fold increase (Table 1). Similar results were obtained later when the same experiment was carried out using $0.2 \mathrm{~cm}$ cuvettes. Transformants were not obtained in the absence of plasmid DNA or the pulse.

In order to determine whether the efficiency of transformation could be increased further, different concentrations of glycine and INH were added to the growth medium, separately and in combination (Figs 1 and 2). Fig. 1 shows that when glycine alone (up to $6.5 \%$ ) was added to the growth medium, the number of transformants obtained following electroporation with pUL340 was never as high as when cells were grown with glycine plus $4 \mathrm{mg} \mathrm{INH} \mathrm{ml}^{-1}$. As the concentration of

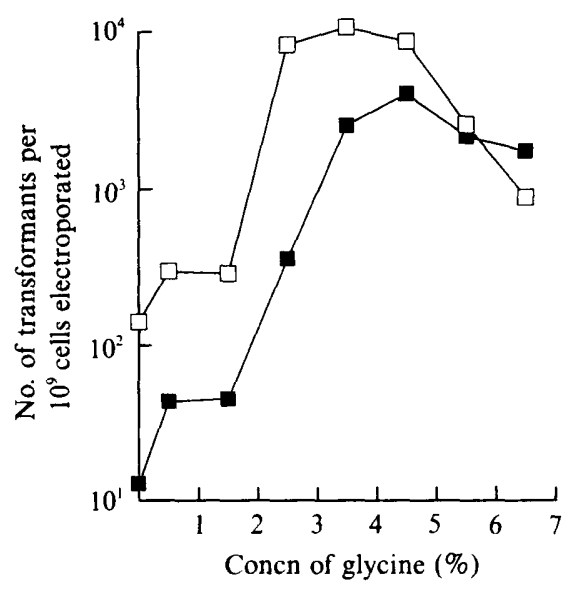

Fig. 1. Effect of glycine in the growth medium on the number of transformants obtained. C. glutamicum AS019 was cultured in LBG containing $0-6.5 \%$ glycine (G) or LBG supplemented with $4 \mathrm{mg} \mathrm{INH}$ $\mathrm{ml}^{-1}$ plus $0-6.5 \%$ glycine $(\square)$. Cells were harvested when $\mathrm{OD}_{600}$ was 0.2 and then subjected to electroporation in a $0.4 \mathrm{~cm}$ cuvette in the presence of $1 \mu \mathrm{g}$ plasmid pUL340.

Table 1. Effects of growth in LBG containing glycine and INH on electroporation transformation frequencies

C. glutamicum AS019 cells were harvested when the $\mathrm{OD}_{600}$ was 0.2. After electroporation transformants were recovered on ET$\mathrm{Km}$ plates.

\begin{tabular}{lcc}
\hline \hline \multirow{2}{*}{$\begin{array}{c}\text { Growth } \\
\text { supplement }\end{array}$} & \multicolumn{2}{c}{ No. of transformants $(\mu \mathrm{g} \mathrm{DNA})^{-1}$} \\
\cline { 2 - 3 } & $0.4 \mathrm{~cm}$ cuvette* & $0.2 \mathrm{~cm}$ cuvette $\dagger$ \\
\hline None & $2.0 \times 10^{2}$ & $1.4 \times 10^{4}$ \\
Glycine $2.5 \%(\mathrm{w} / \mathrm{v})$ & $1.8 \times 10^{3}$ & $7.2 \times 10^{4}$ \\
$\begin{array}{l}\text { Glycine } 2.5 \%(\mathrm{w} / \mathrm{v}) \\
\text { plus INH }\left(4 \mathrm{mg} \mathrm{ml}{ }^{-1}\right)\end{array}$ & $9.9 \times 10^{3}$ & $5.2 \times 10^{5}$ \\
\hline \hline
\end{tabular}

* pCSL17 DNA $(1 \mu \mathrm{g})$ isolated from C. glutamicum AS019 was added to $0.8 \mathrm{ml}$ cells $\left(\sim 10^{9}\right.$ cells $)$ suspended in electroporation buffer prior to pulsing at $2.5 \mathrm{kV}$ and $25 \mu \mathrm{F}$.

$\dagger$ pCSL17 DNA $(0 \cdot 1 \mu \mathrm{g})$ isolated from C. glutamicum AS019 was added to $40 \mu \mathrm{l}$ cells $\left(\sim 10^{9}\right.$ cells) suspended in $15 \%$ glycerol prior to pulsing at $2.5 \mathrm{kV}$ and $25 \mu \mathrm{F}$.

glycine in the growth medium increased, the efficiency of transformation (transformants per $10^{9}$ cells treated) increased, with the highest number of transformants seen following growth in $2 \cdot 5-4.5 \%$ glycine plus $4-8 \mathrm{mg}$ INH $\mathrm{ml}^{-1}$. However, increasing the concentration of glycine above $4.5 \%$ resulted in a decrease in the number of transformants obtained. Supplementing LBG with INH alone also improved transformation efficiency but even at the highest concentration tested $\left(12 \mathrm{mg} \mathrm{m}^{-1}\right)$, INH was not as effective alone as when it was used in combination with glycine. As growth was severely inhibited at high glycine and INH concentrations, LBG 


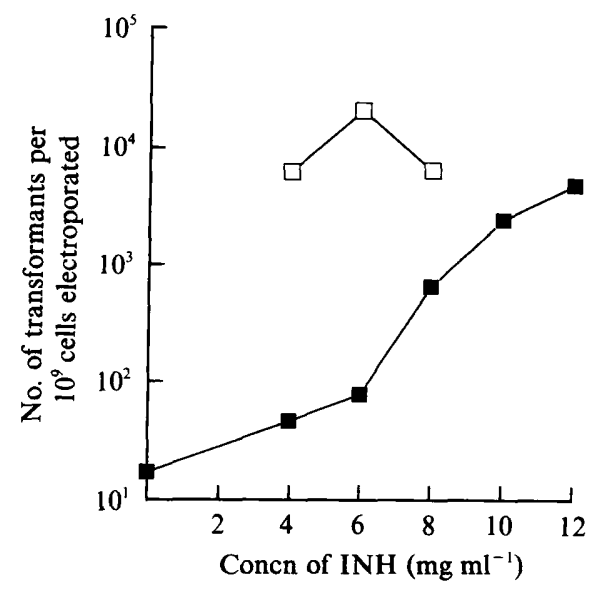

Fig. 2. Effect of INH concentration in the growth medium on the number of transformants obtained. C. glutamicum AS019 was cultured in LBG $(\square)$ or LBG containing $2.5 \%$ glycine $(\square)$ in the presence of 0-12 $\mathrm{mg} \mathrm{INH} \mathrm{ml}^{-1}$. Growth and electroporation conditions were as Fig. 1.

was supplemented routinely with $2.5 \%$ glycine and $4 \mathrm{mg}$ INH ml ${ }^{-1}$ in subsequent experiments.

The growth inhibition and presumed increase in cell surface permeability produced by glycine and INH are probably due to different mechanisms. Glycine is incorporated into the Gram-positive cell wall in place of D-alanine. However, its incorporation is less efficient and leads to less cross-linking and a looser wall structure (Hammes et al., 1973). It has been suggested that this looser structure is a better substrate for lysozyme and our data suggest that this may facilitate increased uptake of DNA by $C$. glutamicum during electroporation. Cells of C. glutamicum grown in the presence of glycine elongate and bulge at sites where the cell wall is apparently weakened or damaged (Best \& Britz, 1986; SerwoldDavis et al., 1987). The concentration of glycine used in the growth medium for corynebacteria prior to lysozyme treatment and protoplast transformation has varied greatly between laboratories $(0 \cdot 5 \%-2 \cdot 5 \%)$. SerwoldDavis et al. (1987) found that when the levels of glycine inhibited cell growth substantially, corresponding to the formation of exaggeratedly misshapen cells, then these cells were resistant to the effects of lysozyme. We have found that when C. glutamicum was grown in very high concentrations of glycine, the efficiency of electroporation increased, suggesting that further modifications to cell surface structures may have been occurring which were important for DNA uptake.

INH only inhibits the growth of mycobacteria and other mycolic-acid-containing bacteria. With Mycobacterium, Nocardia and Rhodococcus strains, concentrations of INH from $1 \mu \mathrm{g} \mathrm{ml}^{-1}$ to $100 \mu \mathrm{g} \mathrm{ml}^{-1}$ have been shown to cause significant inhibition of growth (Tomiyasu \& Yano, 1984). In these bacteria, the incorporation of INH in the growth medium decreases both the ratio of mycolic to non-mycolic fatty acids and the mean carbon atom length of the mycolic acids (Tomiyasu \& Yano, 1984; Maekura, 1984). However, at levels of INH up to $100 \mu \mathrm{g} \mathrm{ml}^{-1}$, neither growth inhibition nor change in the corynomycolic acid composition was observed in Corynebacterium xerosis and Rhodococcus rhodochrous (Tomiyasu \& Yano, 1984).

Yoshihama et al. (1985) reported that the incorporation of INH into the growth medium had no effect on protoplast formation or transformation in C. glutamicum. However, the concentration used was not stated and it is possible that much lower concentrations than we have used were tested. It is significant that the levels we have found to be useful as a pretreatment for electroporation with $C$. glutamicum are much higher (i.e. $4 \mathrm{mg} \mathrm{m}^{-1}$ ) than those used by Tomiyasu \& Yano (1984): at lower concentrations of INH, growth of $C$. glutamicum is not affected (M. L. Britz, unpublished). Although the effects of high concentrations of INH on mycolic acid synthesis have not been evaluated in C. glutamicum, our observations using phase-contrast microscopy have shown that cells grown in the presence of INH exhibit distorted shapes (longer, rounded cells) consistent with the postulated modification of the cell surface.

It appears that the optimum electroporation transformation obtained by growing cells in the presence of glycine and INH arises from a combination of two effects: the glycine producing a less cross-linked peptidoglycan and the INH possibly causing formation of mycolic acids of shorter chain-length. Both probably decrease the physical barrier to the uptake of DNA.

\section{Effect of growth phase on electroporation transformation efficiency}

Cultures of C. glutamicum grown in LBG (supplemented with glycine and INH) were harvested after 16-18 h growth when the $\mathrm{OD}_{600}$ ranged between 0.075 and 4.5 . It was found that early exponential phase cells were more easily transformed with pCSL17 DNA and that as the $\mathrm{OD}_{600}$ increased, there was a significant reduction in the number of transformants obtained (Fig. 3). This was true whether $0.4 \mathrm{~cm}$ or $0.2 \mathrm{~cm}$ cuvettes were used. In most experiments, cells were routinely harvested when $\mathrm{OD}_{600}$ was between $0 \cdot 15$ and $0 \cdot 25$.

Cells harvested in the early to mid-exponential growth phase have generally been found to be optimal for electroporation (Miller et al., 1988; Powell et al., 1988; Dower et al., 1988). Powell et al. (1988), working with lactic streptococci, found that the number of transformants recovered was not affected in the optical density range of $0 \cdot 25-0 \cdot 7$. However, when cells were harvested at an $\mathrm{OD}_{600}$ of 0.9 , the number of transformants recovered 


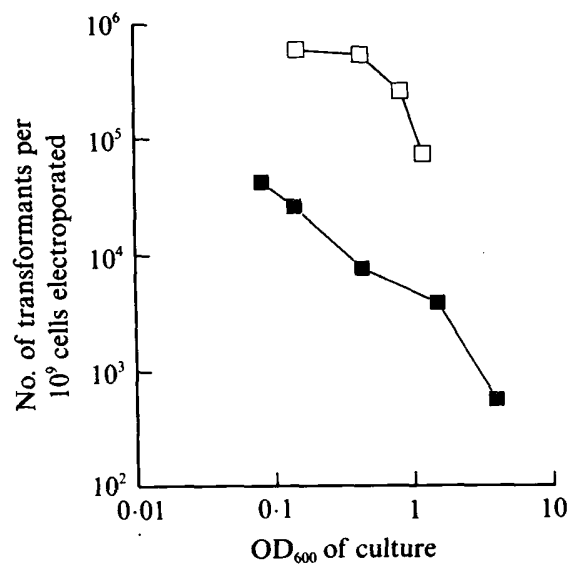

Fig. 3. Effect of harvesting cultures at different growth phases on the number of transformants obtained using electroporation. C. glutamicum AS019 was grown in LBG supplemented with $2.5 \%$ glycine and 4 $\mathrm{mg} \mathrm{INH} \mathrm{ml} \mathrm{m}^{-1}$ and subjected to electroporation in the presence of pCSL17 DNA in $0.2 \mathrm{~cm}(\square)$ or $0.4 \mathrm{~cm}(\square)$ cuvettes as described in Methods.

decreased by $15 \%$. The stage of growth required for efficient electroporation transformation of C. glutamicum appears to be more critical than found for other genera to date. This may be related to the composition of the cell surface, as we have found that the mycolic acid composition of strain AS019 and auxotrophic mutants (Best \& Britz, 1986) varies during the growth cycle (D. Pierotti and others, unpublished).

\section{Effect of the concentration of DNA and cells on the number of transformants}

The relationship between DNA concentration and number of recombinants recovered for all three plasmids tested was linear (Fig. 4). The transformation efficiencies (no. of transformants $\mu \mathrm{g}^{-1}$ ) for these points were constant within experimental variation: means \pm SD were pCSL17, $1.5 \pm 0.5 \times 10^{4}{\mu \mathrm{g}^{-1}}_{\text {; }}$ pUL340, 9.2 \pm 1.2 $\times 10^{3} \mu \mathrm{g}^{-1}$ and $\mathrm{pHY} 416, \mathrm{Cm} / \mathrm{Km} 5.9 \pm 1.4 \times 10^{3} \mu \mathrm{g}^{-1}$. The size of the plasmid appeared to have no effect on the relative ease of transformation but the size range of the plasmids tested was small. No clear-cut relationship has been observed between plasmid size and transformation by electroporation, and large plasmids, exceeding $25 \mathrm{~kb}$, have been introduced efficiently into Lactobacillus and Streptococcus spp. (Powell et al., 1988). With E. coli (Dower et al., 1988) and Campylobacter jejuni (Miller et al., 1988), the relationship between DNA concentration and the number of transformants is also linear over several orders of magnitude and a constant efficiency of transformation is obtained. DNA saturation has not been reported with any bacteria using electroporation

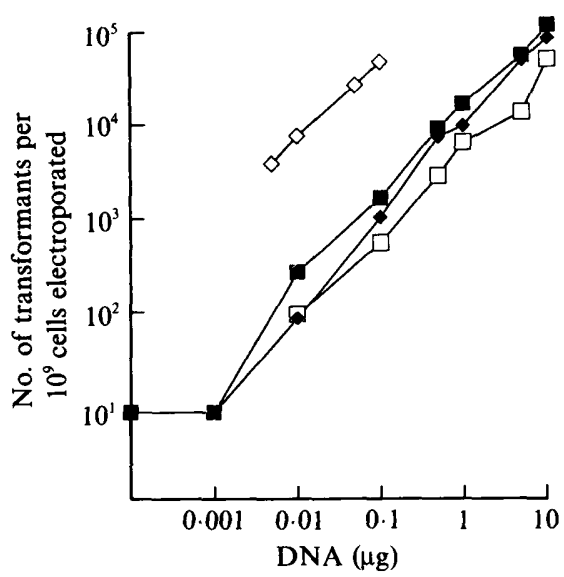

Fig. 4. Relationship between the number of transformants and the amount of DNA used. C. glutamicum AS019 cells were electroporated in the presence of pCSL17 ( $\square)$, pHY416 Cm/Km ( $\square$ ) or pUL340 $(\bullet)$ in $0.4 \mathrm{~cm}$ cuvettes, and pUL340 in $0.2 \mathrm{~cm}$ cuvettes $(\diamond)$. For conditions of growth and electroporation see Methods.

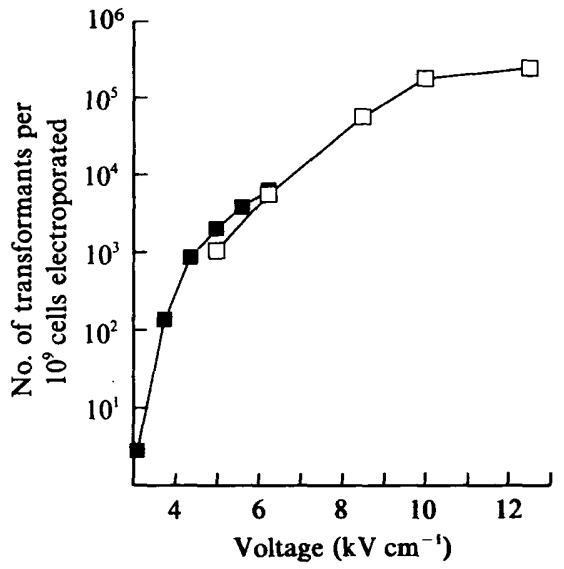

Fig. 5. Effects of voltage on transformation efficiency. C. glutamicum AS019 cells were electroporated in the presence of PCSL17 DNA in the $0.4 \mathrm{~cm}(\square)$ and $0.2 \mathrm{~cm}(\square)$ cuvettes. For growth and electroporation conditions see Methods.

and it appears that the level at which saturation occurs is much greater than that observed with other transformation procedures.

A linear relationship was also observed when $1 \mu \mathrm{g}$ pCSL17 DNA was pulsed in the presence of cells at concentrations of approximately $1 \times 10^{6}$ c.f.u. to $1 \times$ $10^{9}$ c.f.u. (data not shown).

Effect of voltage $\left(\mathrm{kV} \mathrm{cm}^{-1}\right)$ on the number of cells transformed

C. glutamicum cells and pCSL17 were exposed to voltages from 3.1 to $6.25 \mathrm{kV} \mathrm{cm}^{-1}$ in $0.4 \mathrm{~cm}$ cuvettes and voltages from 5.0 to $12.5 \mathrm{kV} \mathrm{cm}^{-1}$ in $0.2 \mathrm{~cm}$ cuvettes (Fig. 5). 
Table 2. Effect of selection medium and recovery time following electroporation on the number of transformants obtained

\begin{tabular}{lllcc}
\hline $\begin{array}{l}\text { Recovery } \\
\text { medium }\end{array}$ & Diluent & $\begin{array}{c}\text { Recovery } \\
\text { time }\end{array}$ & $\begin{array}{c}\text { Transformants* } \\
(\mu \mathrm{g} \mathrm{DNA})^{-1}\end{array}$ & $\begin{array}{c}\text { Percentage of } \\
\text { maximum }\end{array}$ \\
\hline ET-Km & SMMC & $1 \mathrm{~h} \dagger$ & $5.8 \times 10^{4}$ & 100 \\
NAG-Km & SMMC & $1 \mathrm{~h} \dagger$ & $1.1 \times 10^{4}$ & 19 \\
ET-Km & SMMC & None & $1.2 \times 10^{4}$ & 21 \\
NAG-Km & SMMC & None & $<1.5 \times 10^{1}$ & $<0.03$ \\
ET-Km & DW $\ddagger$ & None & $9.3 \times 10^{2}$ & 1.6 \\
NAG-Km & DW $\ddagger$ & None & $<1.5 \times 10^{1}$ & $<0.03$ \\
\hline \hline
\end{tabular}

* C. glutamicum AS019 was grown to an $\mathrm{OD}_{600}$ of 0.2 in LBG containing $2.5 \%$ glycine plus $4 \mathrm{mg} \mathrm{INH} \mathrm{ml}^{-1}$, harvested, then electroporated in a $0.4 \mathrm{~cm}$ cuvette in the presence of $1 \mu \mathrm{g}$ of pUL340 DNA.

† Cells were incubated at $30^{\circ} \mathrm{C}$ in LBG for $1 \mathrm{~h}$ with gentle shaking. Viable counts did not increase during this period.

$\ddagger \mathrm{DW}$, distilled water.

Although the buffer and the volume of cells were different when using the $0.4 \mathrm{~cm}$ and $0.2 \mathrm{~cm}$ cuvettes, Fig. 3 shows that there appears to be a good correlation between the two methods once account is made for the different amounts of DNA supplied. The best results were obtained at $12.5 \mathrm{kV} \mathrm{cm}^{-1}$ and $25 \mu \mathrm{F}$, the maximum possible values obtainable with the Bio-Rad Gene Pulser, conditions found to be the most efficient for other bacteria (Dower et al., 1988). However, one exception is Streptococcus: using 0.4 cm cuvettes, Powell et al. (1988) found that $\left.2.0 \mathrm{kV}(4 \mathrm{kV} \mathrm{cm})^{-1}\right)$ gave higher numbers of transformants than $2.5 \mathrm{kV}\left(6.25 \mathrm{kV} \mathrm{cm}^{-1}\right)$.

\section{Effect of the recovery medium used to isolate transformants}

Following electroporation of cells with pUL340 DNA, and incubation at $30^{\circ} \mathrm{C}$ for $1 \mathrm{~h}$, the cells were diluted and spread onto three selective media: ET-Km, LAG-Km and NAG-Km. Transformants grew faster on the osmotically protective medium (ET-Km) and this was also the medium which consistently supported the highest number of colonies (data not shown). The degree of superiority of ET-Km over NAG-Km and LAG-Km showed some variability from experiment to experiment but counts on ET-Km were usually at least $70 \%$ higher than those on NAG-Km and LAG-Km. This was true whether cells were pulsed at $6.25 \mathrm{kV} \mathrm{cm}^{-1}(0.4 \mathrm{~cm}$ cuvette) or $12.5 \mathrm{kV} \mathrm{cm}^{-1}(0.2 \mathrm{~cm}$ cuvette).

Total viable counts were carried out on both ET and NAG plates before and after electroporation. There was no significant difference in the viable counts obtained on the two media or from cells diluted in distilled water prior to plating on NAG. This suggests that most of the cells were not osmotically fragile following growth in
LBG/glycine/INH or after electroporation. However, the data presented in Table 2 show that transformants arising following electroporation were osmotically or electrochemically fragile, as dilution in distilled water or plating directly onto NAG-Km after diluting in SMMC resulted in substantially fewer transformants. This phenomenon was not caused by a lack of expression time, although the number of transformants did increase five-fold after a recovery period, as selection onto high ionic strength, osmotically-protective medium (ET-Km) increased the number of transformants 10 - to $10^{3}$-fold. This fragility was lost after a recovery period (compare counts on NAG-Km before and after recovery). Osmotic or electrochemical fragility has not, to our knowledge, been reported for any other electroporation system. However, Powell et al. (1988) showed that over $90 \%$ of the transformants recovered were derived from osmotically fragile cells following mild lysozyme treatment of Streptococcus lactis. We have found that mild lysozyme treatment $\left.(1 \mathrm{kU} \mathrm{ml})^{-1}\right)$ of $C$. glutamicum improved electroporation transformation efficiency approximately five-fold.

\section{Comparison of $0.4 \mathrm{~cm}$ and $0.2 \mathrm{~cm}$ cuvettes}

Initial experiments were carried out using the $0.4 \mathrm{~cm}$ cuvettes and with cells suspended in a sucrose/phosphate buffer according to methods supplied by Bio-Rad. However, when the $0.2 \mathrm{~cm}$ cuvettes became available, these were used instead and the cells were suspended in $15 \%$ glycerol. The latter method was found to increase the transformation efficiency from approximately $10^{4}$ $(\mu \mathrm{g} \text { DNA })^{-1}$ to $10^{5}$ ( $\mu \mathrm{g}$ DNA $)^{-1}$ and the transformation frequency (no. of transformants per survivor) from approximately $1.0 \times 10^{-6}$ to $5.0 \times 10^{-5}$, using 


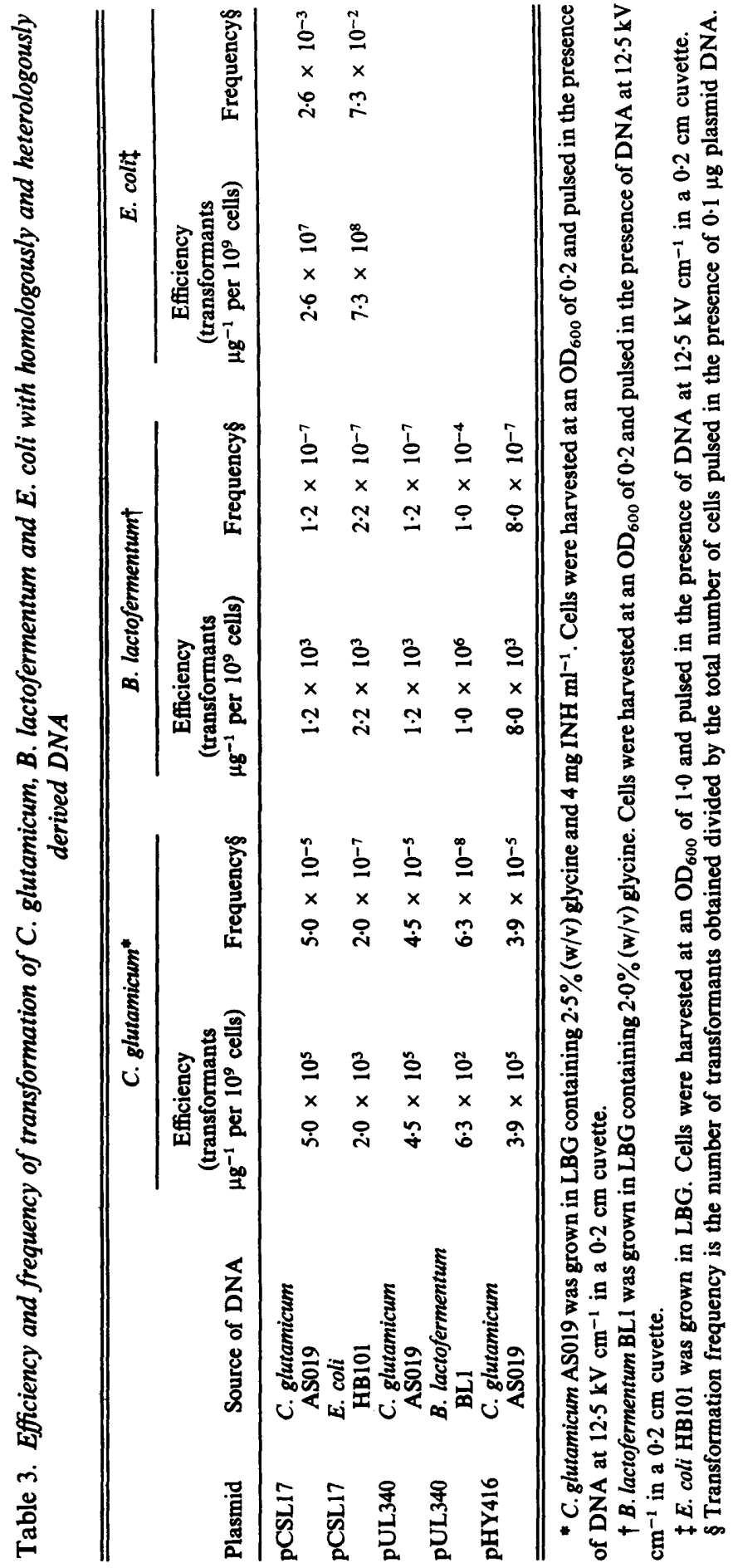


homologously isolated DNA. Two other C. glutamicum strains, CG2 and MLB131, gave similar results. We have found that using the same strains and plasmids, electroporation represents at least a 10- to 100-fold improvement in transformation efficiency over our spheroplast transformation methods. We have used a similar approach in developing an electroporationtransformation method for $B$. lactofermentum (see Table 3 for transformation efficiencies), where the pretreatment conditions differ from those required for $C$. glutamicum (J. A. Haynes \& M. L. Britz, unpublished).

The number of cells killed during electroporation was variable. Using the $0.4 \mathrm{~cm}$ cuvettes at $6.25 \mathrm{kV} \mathrm{cm}^{-1}$, less than $30 \%$ of cells were killed, whereas when the $0.2 \mathrm{~cm}$ cells were used at $12.5 \mathrm{kV} \mathrm{cm}^{-1}$, up to $50 \%$ of cells were killed. With $E$. coli the maximum transformation frequencies were obtained when $50-75 \%$ of cells were killed (Dower et al., 1988).

\section{Restriction barriers to transformation}

Table 3 indicates that restriction barriers exist between C. glutamicum, B. lactofermentum and E. coli. C. glutamicum and $B$. lactofermentum are sufficiently related to enable both to use the origins of replication of pUL340 and pCSL17. However, the barrier to transformation was as great between these two species as that seen for $E$. coli-derived DNA.

Other workers have also found that restriction barriers exist between E. coli, B. lactofermentum and C. glutamicum. Yeh et al. (1986) found that $B$. lactofermentum could be transformed at a frequency of $1.5 \times 10^{5}$ transformants $\mu \mathrm{g}^{-1}$ with homologously isolated DNA whereas DNA isolated from C. glutamicum only gave $2.8 \times 10^{1}$ transformants ( $\mu$ g DNA) ${ }^{-1}$. Serwold-Davis et al. (1987) found that $C$. glutamicum was transformed with homologous DNA at $10^{3}$ transformants $\mu \mathrm{g}^{-1}$ but with heterologous DNA from $C$. diphtheriae and $E$. coli only $10^{1}$ transformants $\mu \mathrm{g}^{-1}$ and $10^{-1}$ transformants $(\mu \mathrm{g} \text { DNA) })^{-1}$ were obtained, respectively.

\section{Conclusions}

We have found electroporation to be an efficient and rapid method of transforming $C$. glutamicum. The frequency and efficiency of transformation are comparable with those obtained by other authors using spheroplast or protoplast transformation (Yoshihama et al., 1985; Thierbach et al., 1988). Using the same strains and plasmids, we have found an increase in transformation efficiency of 10 - to 100 -fold using electroporation, relative to spheroplast or protoplast transformation methods.
Several factors influence the number of transformants obtained. There is a linear relationship between both the concentration of the cell suspension and the amount of DNA added and number of cells transformed. The maximum voltage and capacitance available using the Bio-Rad Gene Pulser were required to achieve high levels of transformation. The addition of glycine (2.5$4.5 \%)$ and INH $\left(4 \mathrm{mg} \mathrm{ml}^{-1}\right)$ to the growth medium and harvesting cells in early exponential phase were found to be important prerequisites for efficient electroporation. Finally, the recovery medium on which the transformants were isolated had a significant effect on the number of transformants obtained. The osmotically protective $(\mathrm{ET}-\mathrm{Km})$ medium was better than NAG-Km or LAG-Km as a recovery medium suggesting that cells successfully transformed by electroporation were electrochemically or osmotically sensitive.

We have found that, despite the restriction barriers which exist between $C$. glutamicum, B. lactofermentum and $E$. coli, we were able to transform heterologously isolated DNA between species, although at a reduced frequency.

We are grateful to Gregory Kemp for capable technical assistance. We also thank Professors J. F. Martín, A. Sinskey and P. Rogers for providing some of the corynebacterial plasmids and strains.

\section{References}

Allen, S. P. \& BlascheK, H. P. (1988). Electroporation-induced transformation of intact cells of Clostridium perfringens. Applied and Environmental Microbiology 54, 2322-2324.

BEST, G. R. \& BRITZ, M. L. (1986). Facilitated protoplasting in certain auxotrophic mutants of Corynebacterium glutamicum. Applied Microbiology and Biotechnology 23, 288-293.

BRITZ, M. L. \& BEST, G. R. (1986). Expression of chloramphenicol resistance specified by plasmid pHY416 hosted in Corynebacterium glutamicum. Current Microbiology 14, 13-17.

Chassy, B. M. \& Flickinger, J. L. (1987). Transformation of Lactobacillus casei by electroporation. FEMS Microbiology Letters 44, 173-177.

Dower, W. J., Miller, J. F. \& Ragsdale, C. W. (1988). High efficiency transformation of $E$. coli by high voltage electroporation. Nucleic Acids Research 16, 6127-6145.

Hammes, W., SCHLeifer, K. H. \& KandLeR, O. (1973). Mode of action of glycine on the biosynthesis of peptidoglycan. Journal of Bacteriology 116, 1029-1053.

Katsumata, R., Ozaki, A., OKa, T. \& Furuya, A. (1984). Protoplast transformation of glutamate-producing bacteria with plasmid DNA. Journal of Bacteriology 159, 306-311.

MAEKURA, R. (1984). Effect of isonicotinic acid hydrazide on mycolic acid synthesis in Nocardia rubra. Kekkaku 59, 435-440.

Maniatis, T., Fritsch, E. F. \& SAMBrook, J. (1982). Molecular Cloning: a Laboratory Manual. Cold Spring Harbor, NY: Cold Spring Harbor Laboratory.

Martin, J. F., Santamaria, R., Sandoval, H., Del Real, G., Mateos, L. M., Gil, J. A. \& Aguilar, A. (1987). Cloning system in amino acid-producing corynebacteria. Biotechnology 5, 137-147.

MiLLER, J. H. (1972). Experiments in Molecular Genetics. Cold Spring Harbor, NY: Cold Spring Harbor Laboratory. 
Miller, J. F., Dower, W. J. \& Tomkins, L. S. (1988). High voltage electroporation of bacteria : genetic transformation of Campylobacter jejuni with plasmid DNA. Proceedings of the National Academy of Sciences of the United States of America 85, 856-860.

Powell, I. B., AChen, M. G., Hillier, A. J. \& Davidson, B. E. (1988) A simple and rapid method for genetic transformation of lactic streptococci by electroporation. Applied and Environmental Microbiology 54, 655-660.

RALEIGH, E. A. (1987). Restriction and modification in vivo by Escherichia coli K12. Methods in Enzymology 152, 130-141.

Santamaria, R., Gil, J. A., Mesas, J. M. \& Martin, J. F. (1984). Characterization of an endogenous plasmid and development of cloning vectors and a transformation system in Brevibacterium lactofermentum. Journal of General Microbiology 130, 2237-2246.

SANTAMaria, R. I., GIL, J. A. \& MarTin, J. F. (1985). High-frequency transformation of Brevibacterium lactofermentum by plasmid DNA. Journal of Bacteriology 162, 463-467.
Serwold-Davis, T. M., Groman, N. \& Rabin, M. (1987). Transformation of Corynebacterium diphtheriae, Corynebacterium ulcerans, Corynebacterium glutamicum, and Escherichia coli with the $C$. diphtheriae plasmid pNG2. Proceedings of the National Academy of Sciences of the United States of America 84, 4964-4968.

ThIERBACH, G., SCHWARZER, A. \& PUHLER, A. (1988). Transformation of spheroplasts and protoplasts of Corynebacterium glutamicum. Applied Microbiology and Biotechnology 29, 356-362.

TOMIYASU, I. \& YANO, I. (1984). Isonicotinic acid hydrazide induced changes and inhibition in mycolic acid synthesis in Nocardia and related taxa. Archives of Microbiology 137, 316-323.

Yeh, P., Oreglia, J., Prevots, F. \& Sicard, A. M. (1986). A shuttle vector system for Brevibacterium lactofermentum. Gene 47, 301-306.

Yoshihama, M., Higashiro, K., Rao, E. A., AKedo, M., Shanabruch, W. G., FolletTiE, M. T., WALKeR, G. C. \& SinSKEY, A. J. (1985) Cloning vector system for Corynebacterium glutamicum. Journal of Bacteriology 162, 591-597. 